\title{
A review on community scale stationary and mobile production of biodiesel
}

\author{
Muhammad Yusuf Abduha,b*, Robert Manurunga ${ }^{a}$, Hero Jan Heeres ${ }^{c}$, Noor Illi Mohamad Puad \\ aschool of Life Sciences and Technology, Institut Teknologi Bandung, Indonesia \\ ${ }^{b}$ University Center of Excellence for Nutraceuticals, Bioscience and Biotechnology Research Center, Institut Teknologi Bandung, Indonesia \\ 'Department of Chemical Engineering, University of Groningen, Nijenborgh 4, 9747 AG, the Netherlands \\ ${ }^{d}$ Bioprocess and Molecular Engineering Research Unit, Department of Biotechnology Engineering, Kulliyyah of Engineering, International \\ Islamic University Malaysia, P.O. Box 10, 50728 Kuala Lumpur, Malaysia
}

\begin{abstract}
Biodiesel has been commercially produced on a large scale, but its application is still limited primarily due to its production cost, which is relatively more expensive than that of fossil fuel. Recently, there has been an ongoing parallel development whereby biodiesel production is carried out on a community scale, including a mobile production unit of biodiesel with local input and demand. The produced biodiesel is often intended for use by the concerned local community, which greatly reduces logistics and transportation cost. A mobile biodiesel unit typically consists of biodiesel processing units placed inside a truck which can travels from one location to another particularly to the source of the feedstock. This article reviews the community scale production of biodiesel carried out in mobile biodiesel units and at fixed locations. These include pre-treatment of the feedstock such as isolation of oil from oilseeds and quality control of oil prior to the reaction unit, the reactor technology to produce crude biodiesel as well the post treatment for producing the refined biodiesel that meets the international specification. This paper also discusses the cost for producing biodiesel in a community scale particularly for the case of a mobile biodiesel unit. The production cost varies from $\$ 0.76-1.12 / 1$. This range is still not yet competitive to the current average price of approximately $\$ 0.98 / 1$ of diesel around the world. The production cost may be reduced by applying a biorefinery concept that is economically attractive with an environmental benefit.
\end{abstract}

\section{Article history:}

Received 26 Jan 2021

Revised 21 Feb 2021

Accepted 26 Feb 2021

Available online 28 Feb 2021

\section{Keywords:}

Biodiesel

community scale

mobile biodiesel unit

production cost * Corresponding authors:
yusuf@sith.itb.ac.id

\section{Introduction}

Biodiesel can be synthesised from triglyceride of plant oil animal fats (Balat, 2007; Marchetti et al., 2007; Mishra and Goswani, 2018; Abduh et al., 2018). It has been reported that there is more than 350 feedstock that can be used to produce biodiesel, depending on several factors particularly the oil yield, productivity, production cost and oil characteristics (Atabani et al., 2012). Biodiesel has been commercially produced on different scales particularly at large scale (100-250 kiloton/yr), the processing technology has higher efficiencies at the expense of exorbitant capitalization and on-site construction. The raw material, typically vegetable oil used as a feedstock, is either imported or available from dedicated plantations. The transport of raw material from the plantation and the produced biodiesel to the consumer generally requires high transportation costs (Bernesson et al., 2004).

Biodiesel can also be produced on a small scale $(<15$ kiloton/yr), which requires a relatively simple and cheaper equipment which can be applied in remote areas. As such may reduce the capital investment as well as logistic and distribution cost (Bernesson et al., 2004). Recently, there has been an ongoing parallel development whereby small-scale biodiesel units are considered for mobile purposes using local sources for local market. A mobile biodiesel unit typically consists of biodiesel processing units placed inside a truck which can travels from one location to another particularly to the source of the feedstock. (Bhachu et al., 2005; Teal and Sickels, 2005; Patten, 2005; Keady, 2008; Baum and
Kelly, 2009; Oliveira et al., 2009; Brasil, 2011; Rummer, 2013). The biodiesel product is also intended for use by the concerned local community. In addition, the mobile biodiesel unit can reach smallscale oilseed producers scattered in remote locations, particularly in the less developed regions.

This article reviews the community scale production of biodiesel carried out in mobile biodiesel units and at fixed locations. These include pre-treatment of the feedstock such as isolation of oil from oilseeds and quality control of oil prior to the reaction unit, the reactor technology to produce crude biodiesel as well the post treatment for producing the refined biodiesel that meets the international specification. This paper also discusses the cost for producing biodiesel in a community scale particularly for the case of a mobile biodiesel unit.

\section{Conventional production of biodiesel}

\subsection{Raw materials}

Previous studies have reported that the feedstock cost represents approximately $75 \%$ of the overall cost for the production of biodiesel (Haas et al., 2006; Singh et al., 2007; Silitonga et al., 2011; Lin et al., 2011; Ragit et al., 2011; Atabani et al., 2012). Hence, the selection of suitable raw materials is crucial for producing biodiesel. The raw materials can generally be categorized into four categories, viz.: (i) edible oil, (ii) non-edible oil, iii) waste or recycled oil, and (iv) animal fats (Singh et al., 2007; Balat and Balat, 2010; Lin et al., 2011; Ragit et al., 2011; Balat, 2011). It has been reported that most biodiesel are currently produced from 
edible oils particularly rapeseed $(84 \%)$, sunflower oil $(13 \%)$, palm oil $(1 \%)$, and other sources $(2 \%)$. However, the use of edible oils for producing biodiesel results in the increase of vegetable oil price, deforestation, and escalating disparity between demand and supply of the edible oils in many countries (Balat and Balat, 2010; Balat, 2011; Deng et al., 2011).

Non-edible oils such as rubber seed and Jatropha seed are considered as promising alternatives as raw materials for producing biodiesel as they can eliminate the competition for food. Animal fats and waste cooking oil may be valorised as a feedstock to synthesize biodiesel. However, their availability would not be sufficient to fulfil the demand of energy worldwide (Atabani et al., 2012). The animal fats and waste cooking oil typically have a relatively high acid value which may impedes the transesterification reaction and decreases the biodiesel yield (Atadashi et al., 2011; Oh et al., 2012; Abduh et al., 2016). Several alternatives of biodiesel feedstock are presented in Table 1 . The data shows that the oil productivity varies due to the oil content and yield of the oil isolation process. Microalgae have a very high productivity compared to other raw materials. Hence, microalgae are considered as a promising feedstock to produce biodiesel, but its commercialization is hindered by a high production cost.

Recent studies have shown that blending different oils can improve the property of the synthesised biodiesel (Sarin et al., 2007; Sarin et al., 2009; Jena et al., 2010). Several studies have reported that switchgrass, poplar and miscanthus that have been genetically engineered are promising raw materials to produce biodiesel (Janaun and Elis, 2010; Lin et al., 2011).

Table 1. Estimated oil content and productivity of different raw materials for producing biodiesel (Atabani et al., 2012)

\begin{tabular}{lll}
\hline Raw material & Oil content (\%) & Oil productivity (L/ha/yr) \\
\hline Rubber seed & $40-50$ & $80-120$ \\
Soybean & $15-20$ & 446 \\
Sunflower seed & $25-35$ & 952 \\
Rapeseed & $38-46$ & 1190 \\
Castor bean & 53 & 1413 \\
Jatropha seed & $50-60$ & 1892 \\
Karanja seed & $27-39$ & $225-2250$ \\
Peanut seed & $45-55$ & 2689 \\
Palm & $30-60$ & 5950 \\
Microalgae & $30-70$ & $58700-136900$ \\
\hline
\end{tabular}

\subsection{Isolation of oil}

Isolation of oil using solvent and mechanical pressing are most used techniques to isolate oil from oilseeds. Organic solvents that have a high affinity with the oil contained within oilseeds are typically used in the solvent extraction. Typically, the seeds are pretreated either by heating, cracking, or flaking that can facilitate cell wall rupture by distorting the cells (Becker, 1980). Hexane is one of the commonly used solvents for extraction of oil, but its applications are limited due to environmental concerns. Other alternatives are also used such as ethanol and supercritical carbon dioxide to isolate oil from the oilseeds (Johnson and Lusas, 1983).

Mechanical pressing such as screw and hydraulic presses are very prevalent to isolate oil from oilseeds with and oil recovery lies in the range of $50-80 \%$ (weight basis) which highly depends on the type of the oilseeds (Singh and Bargale, 2000). A screw press is carried out continuously in which the dehulled seeds are typically roasted, conveyed, and milled in-situ (Khan and Hanna, 1983). In contrast, a hydraulic press is operated in a batch mode of operation in which the dehulled seeds are typically crushed and heated at higher temperatures before being pressed at high pressure for a certain time until almost of the oil within the seeds have been recovered (Abduh, 2015; Abduh et al., 2016a).

Numerous researches have been conducted to optimize the process variables in mechanical pressing particularly pressure, time and temperature. The oil recovery can also be increased by several pre-treatment approaches such cracking, dehulling, conditioning, flaking, and drying to obtain smaller particle size and lower moisture content (Khan and Hanna, 1983). It has been reported that hydraulic pressing is considered an appropriate method to isolate oil from the oilseeds to be used as a raw material for communityscale stationary and mobile biodiesel plant particularly in developing countries. The initial cost of investment and operating cost are much lower than using the screw press and solvent extraction processes (Singh and Bargale, 2000).

\subsection{Transesterification}

A lot of studies have been conducted to investigate the properties of plant oils particularly viscosity and volatility that need to be adjusted before the oils can be valorised as an engine fuel (Ma and Hanna, 1999; Al-Zuhair, 2007). There are at least four techniques to overcome the high viscosity of plant oils, viz.: (i) dilution, (ii) pyrolysis, (iii) micro-emulsion, and (iv) transesterification. Numerous researches have been performed to examine the effect of dilution, pyrolysis, and micro-emulsion to develop clean and environmentally safe fuel (Schwab et al., 1987; Fukuda et al., 2001; Helwani et al., 2009). Dilution is a simple process, but a diluted oil often still has a high viscosity, poor volatility, and poor stability (Lin et al., 2011). Micro-emulsion and pyrolysis have been reported as costly techniques that produce biodiesel with a relatively low quality as compared to the international specification (Forson et al., 2004).

Transesterification is a relatively simply and low cost process and is considered as the most established method to produce biodiesel (Sharma and Singh, 2009; Jain and Sharma, 2010; Shahid and Jamal, 2011). During transesterification, triglycerides in the oils or fats react with alcohol (normally methanol) with the help of acid or base catalyst to produce biodiesel which is also known as fatty acid alkyl ester and the by-product glycerol (Freedman et al., 1984; Vicente et al., 2004; Robles-Medina et al., 2009). Transesterification consists of three consecutive reversible reactions whereby triglycerides are transformed stepwise into diglycerides, monoglycerides and glycerol.

A lot of studies have been carried out to determine the effect of various parameters that affect the transesterification particularly acid value and moisture content of the feedstock, type of alcohol and molar ratio, time and temperature of the reaction as well as the stirring mode and speed (Bhachu et al., 2005; Teall and Sickels, 2005; Patten, 2005; Mullard, 2007; Keady, 2008; Baum and Kelly, 2009). Transesterification can be conducted with or without the presence of a catalyst. carried out by catalytic and non-catalytic methods. The non-catalytic method includes the use of supercritical methanol and higher alcohols particularly ethanol, propanol, and butanol. Transesterification with the presence of a catalyst is normally employed to produce biodiesel because alcohol has a low solubility in oils or fats. The addition of a catalyst increases the solubility of alcohol and enhances the rate of reaction. The catalyst can either be homogenous or heterogeneous with homogenous catalysts include alkaline and acid catalysts whereas heterogeneous catalysts include enzymes and alkaline earth metals (Chouhan and Sarma, 2011; Atabani et al., 2012). The typical operating conditions for different transesterification methods are presented in Table 2.

Table 2. Comparison between catalytic and non-catalytic method for the transesterification of plant oils with methanol (Sharma and Singh, 2009; Atabani et al., 2012)

\begin{tabular}{llll}
\hline & $\begin{array}{l}\text { Alkali catalytic } \\
\text { method }\end{array}$ & $\begin{array}{l}\text { Acid catalytic } \\
\text { method }\end{array}$ & $\begin{array}{l}\text { Supercritical } \\
\text { method }\end{array}$ \\
\hline Temperature $\left({ }^{\circ} \mathrm{C}\right)$ & 60 & 60 & $245-295$ \\
Pressure $(\mathrm{MPa})$ & ambient & ambient & $10-25$ \\
Catalyst conc. $(\mathrm{wt} \%)$ & $0.5-1$ & $0.25-2$ & no catalyst \\
Time (min) & $30-60$ & $180-2900$ & $2-4$ \\
Methanol: oil ratio & $6: 1$ & $6: 1$ & $32: 1$ \\
Yield (\%) & 96 & 90 & 98 \\
\hline
\end{tabular}


Based on the data shown in Table 2, a higher yield (98\%) can be achieved in a relatively short period $(2-4 \mathrm{~min})$ by the supercritical method as compared to the alkali- and acid-catalytic method. This method is more environmental-friendly and offer an easier refining of biodiesel and glycerol due to the absence of a catalyst in the reaction (Demirbas and Demirbas, 2007; Canakci and Sanli, 2008; Karmakar et al., 2010). However, this method requires large investment for the reactor and high cost of operation due to elevated pressure and temperature as well as high consumption of methanol.

The alkali- and acid-catalytic method requires only mild temperature and ambient pressure. Sodium and potassium hydroxide are examples of alkaline catalyst that are typically applied in the production of biodiesel. Various studies have reported that alkaline catalysts are the fastest and most economical catalysts. It has been reported that an alkaline catalyst speeds up reactions almost 4000 times faster than similar quantity of an acid catalyst (Atabani et al., 2012). Advantages of using alkaline catalyst are high yield (96\%) and purity of biodiesel within a relatively short period (30-60 min). However, the use of alkaline catalysts requires the free fatty acid (FFA) of the oils below the maximum limit (between 0.5 and 3\%). Formation of soap and reduction in yield is inevitable at FFA levels above 3\% (Demirbaș, 2003; Meher et al., 2006; Canakci and Sanli, 2008; Sharma et al., 2008; Karmakar et al., 2010; Singh and Singh, 2010; Janaun and Ellis, 2010; Deng et al., 2011).

Sulfuric and hydrochloric acids are examples of acid catalysts and there are more tolerant for plant oil with high FFA, and water as compared to the alkaline catalyst. Hence, acid catalysts are typically used to reduce the FFA level below 3\% before transesterification with alkaline catalysts. It has been reported that a high yield ( $90 \%$ ) can be obtained via acid-catalysed reaction after 3-48 h. One of the important issues concerning alkali- and acidcatalytic methods is the refining of biodiesel and glycerol. A lot of water is typically used for production of biodiesel using alkali- and acid-catalytic methods to remove the residual acid or base catalyst and as well as salt produced during the neutralization process (Demirbaș, 2003; Meher et al., 2006; Canakci and Sanli, 2008; Sharma et al., 2008; Karmakar et al., 2010; Singh and Singh, 2010; Janaun and Ellis, 2010; Deng et al., 2011).

\subsection{Specification for biodiesel}

There are two common international standards for biodiesel, viz.: (i) the American Standard Specifications for Biodiesel Fuel (B100) Blend Stock for Distillate Fuel (ASTM D6751) and (ii) the European Standard for Biodiesel (EN 14214). The summary for the EN 14214 specification is given in Table 3. The specifications given by the ASTM D6751 standard (not shown) are very similar to the EN 14214 standard. The major differences lie in their intended application and test methods. The former is for biodiesel intended for diesel engines, whereas the latter is for biodiesel (100\%) to be used use as a blend component with diesel fuels (Cao et al., 2007; Atabani et al., 2012).

\section{Small-scale stationary production of biodiesel}

\subsection{Case 1: Asperhofen Oko-Diesel-projekt, Austria}

The Asperhofen Oko-Diesel-project is an example of a farmer co-operative that produces biodiesel using canola and sunflower oil. The co-operative consists of 290 members that contract 430 ha of land for canola and sunflower plantations, with an average yield of 3 ton/ha, which is approximately 1300 ton of oilseeds (Bender, 1999). Located near Vienna, Austria, the annual production of the community facility in 1992 was 0.4 ton of biodiesel (Bender, 1999), but this increased to 1.5 kiloton in 2007(Martin, 2007). It has been reported that $1000 \mathrm{~L}$ of biodiesel can be synthesised from 3 ton of oilseeds. The biodiesel produced is of high quality and satisfies the minimum European standards for biodiesel. The produced biodiesel is used as fuel by the farmers, whereas the by-product glycerol, which contains potassium hydroxide (the catalyst), is spread as fertilizer on the plantation area with potassium-deficient soil (Bender, 1999).

\subsection{Case 2: Production of biodiesel from non-edible oils in India}

Kalbande et al. (2008) developed a biodiesel processor to produce biodiesel using non-edible oils extracted from Jatropha and Karanja from the local area. The biodiesel production system mainly consists of: (i) a transesterification tank, (ii) a sodium or potassium methoxide mixing tank, (iii) a stirring arrangement, (iv) a settling arrangement, and ( $\mathrm{v}$ ) a bubble wash arrangement. Jatropha fruits were dehulled by a dehuller machine, whereas the Karanja fruits were dehulled manually, and the seeds were separated. The oil was isolated from the seeds using a mechanical screw-type expeller and heated up to $100{ }^{\circ} \mathrm{C}$ to remove moisture. The oil was allowed to cool to $60{ }^{\circ} \mathrm{C}$ before being reacted with methanol (20\%) and $\mathrm{NaOH} / \mathrm{KOH} \quad(0.5-1 \% \mathrm{w})$ in the transesterification vessel. The mixture was mixed vigorously with a mechanical stirrer at $700 \mathrm{rpm}$ for $1.5 \mathrm{~h}$, and a $90 \%$ yield was obtained. The reaction mixture was transferred into a separating funnel for settling by gravity overnight (about $8 \mathrm{~h}$ ). The glycerol was separated, and the biodiesel was bubble-washed with water for 8-24 h to until $\mathrm{pH} 7$ was attained. The specific gravity and kinematic viscosity of the produced biodiesel were found to satisfy the Bureau of Indian Standard Specifications (Kalbande et al., 2008).

The produced biodiesel was blended with diesel and tested in a 7.5-kVa diesel engine generator set. The overall efficiency of the generator set when running on the Jatropha-biodiesel blended fuel was slightly lower than a diesel-fuelled generator. Nevertheless, the biodiesel production system can be used to produce biodiesel that satisfies the Bureau of Indian Standard Specifications using edible and non-edible plant oils via alkali-catalysed transesterification. The system is deemed suitable for community-scale production of biodiesel and can produce about 0.02 ton of biodiesel annually. The system can also be integrated with the local energy systems for community-scale production of biodiesel (Kalbande et al., 2008).

\subsection{Case 3: Production of biodiesel from animal waste in Thailand}

Phalakornkule et al. (2009) reported a community-scale production of biodiesel from animal waste in a remote location in Thailand. The project involved participation from the local community and financial assistance from the government. The system consists of a mixing vessel, a reactor and two washing vessels. The animal waste, particularly pork fat, was collected from local markets. Initially, the fat was filtered by cloth to get rids of food residues. The filtered oil was mixed with $28 \% \mathrm{v}$ methanol and $0.4 \% \mathrm{w} / \mathrm{v} \mathrm{NaOH}$ in a stirred tank reactor for transesterification. The mixture was stirred at $290 \mathrm{rpm}$ and $65^{\circ} \mathrm{C}$. After 1.5 -h reaction time, a yield of $89 \%$ was obtained, with an estimated production capacity of 0.03 ton/yr (Phalakornkule et al., 2009).

Two distinct liquid phases were formed after the mixture was settled in the first washing tank for $2 \mathrm{~h}$. At the top would be the crude ester phase whereas at the at the bottom would be the glycerol phase. After separation, the crude ester phase was washed with water ( $1: 1$ volume ratio) for 3 times. The washed biodiesel was aerated with warm air $\left(40^{\circ} \mathrm{C}\right)$ for $10 \mathrm{~min}$ after each washing step and then heated to $100{ }^{\circ} \mathrm{C}$ for $10 \mathrm{~min}$ (Phalakornkule et al., 2009).

Relevant properties of the purified biodiesel particularly flash point, ash level, free glycerol and several others were determined, all satisfying the biodiesel specification in Thailand for agricultural 
engines. This indicates that the purity of the biodiesel was adequate, and the biodiesel could be used directly in agricultural engines without any operational setbacks (Phalakornkule et al., 2009).

\subsection{Case 4: Production of biodiesel from palm oil in Cameroon}

Sarantopoulos et al. (2009) reported a community-scale production of adequate and affordable biodiesel from locally sourced raw materials like palm oil in rural areas in Cameroon. The produced biodiesel was intended to be used by the local population to fulfil their energy needs. The production system consists of a pretreatment unit, a batch reactor, and a washing unit.

The crude palm oil used as feedstock was obtained from a local market. The FFA level was determined by titration, with an initial value of $8.13 \%$ w obtained, which was far above the $0.5 \%$ level limit for satisfactory transesterification using alkaline catalysts. Therefore, the FFAs were first converted to esters in a pre-treatment process, using an acid catalyst to reduce the FFA content to below $0.5 \%$. This step was then followed by a base-catalysed transesterification step to produce biodiesel. It was determined that the optimum quantity of acid and alcohol for the pre-treatment stage was $0.5 \% \mathrm{H} 2 \mathrm{SO} 4$, catalyst-to-oil ratio, a 6:1 molar ratio of methanol to oil, and a reaction time of $45 \mathrm{~min}$ (Sarantopoulos et al., 2009).

The transesterification reaction was carried out in a batch reactor with a $6: 1$ molar ratio of methanol to oil and a $1 \% \mathrm{w} / \mathrm{v} \mathrm{NaOH}$ as an alkaline catalyst. It involved the mixing of the pre-treated palm oil with methoxide and heating at $55^{\circ} \mathrm{C}$ while stirring for $1 \mathrm{~h}$. The mixture was allowed to settle under gravity. The glycerol was separated, and the esters were washed with water for catalyst recovery. The biodiesel was dried by exposure to the atmosphere for $12 \mathrm{~h}$ (Sarantopoulos et al., 2009).

According to Sarantopoulos et al. (2009), the community-based installation was set to be operated with a production capacity of 1801 of biodiesel per batch with a maximum of 4 batches per day which results to an estimate of 0.14 ton/yr. The number of batches of operation per day may be adjusted depends on the availability of the feedstock as well as the demand by the local community.

Table 3. European standard for biodiesel (Atabani et al., 2012)

\begin{tabular}{|c|c|c|c|c|}
\hline \multirow{2}{*}{ Property } & \multirow{2}{*}{ Method } & \multicolumn{3}{|c|}{ DIN EN 14214} \\
\hline & & Min. & Max. & Unit \\
\hline Ester content & EN 14103 & 96.5 & - & $\%(\mathrm{~m} / \mathrm{m})$ \\
\hline Density $\left(15^{\circ} \mathrm{C}\right)$ & EN ISO 12185 & 860 & 900 & $\mathrm{~kg} / \mathrm{m}^{3}$ \\
\hline Viscosity $\left(40^{\circ} \mathrm{C}\right)$ & EN ISO 3104 & 3.5 & 5 & $\mathrm{~mm}^{2} / \mathrm{s}$ \\
\hline Flashpoint & EN ISO 3679 & 120 & - & ${ }^{\circ} \mathrm{C}$ \\
\hline Sulphur content & EN ISO 20884 & - & 10 & $\mathrm{mg} / \mathrm{kg}$ \\
\hline Cetane number & EN ISO 5165 & 51 & - & - \\
\hline Sulfated ash content & ISO 3987 & - & 0.02 & $\%(\mathrm{~m} / \mathrm{m})$ \\
\hline Water content & EN ISO 12937 & - & 500 & $\mathrm{mg} / \mathrm{kg}$ \\
\hline Total contamination & EN 12662 & - & 24 & $\mathrm{mg} / \mathrm{kg}$ \\
\hline Copper band corrosion $\left(3 \mathrm{~h}, 50^{\circ} \mathrm{C}\right)$ & EN ISO 2160 & Class 1 & Class 1 & rating \\
\hline Oxidation stability $\left(110^{\circ} \mathrm{C}\right)$ & EN 14112 & 6 & - & $\mathrm{h}$ \\
\hline Acid value & EN 14104 & - & 0.5 & $\mathrm{mg} \mathrm{KOH} / \mathrm{g}$ \\
\hline Iodine value & EN 14111 & - & 120 & $\mathrm{~g} \mathrm{I}_{2} / 100 \mathrm{~g}$ \\
\hline Linolenic acid methyl ester & EN 14103 & - & 0.2 & $\%(\mathrm{~m} / \mathrm{m})$ \\
\hline Methanol content & EN 14110 & - & 0.2 & $\%(\mathrm{~m} / \mathrm{m})$ \\
\hline Monoglyceride content & EN 14105 & - & 0.8 & $\%(\mathrm{~m} / \mathrm{m})$ \\
\hline Diglyceride content & EN 14105 & - & 0.2 & $\%(\mathrm{~m} / \mathrm{m})$ \\
\hline Triglyceride content & EN 14105 & - & 0.2 & $\%(\mathrm{~m} / \mathrm{m})$ \\
\hline Free glycerol & EN $14105 / 6$ & - & 0.02 & $\%(\mathrm{~m} / \mathrm{m})$ \\
\hline Total glycerol & EN 14105 & - & 0.25 & $\%(\mathrm{~m} / \mathrm{m})$ \\
\hline Phosphorus content & EN 14107 & - & 4 & $\mathrm{mg} / \mathrm{kg}$ \\
\hline Metals I $(\mathrm{Na}+\mathrm{K})$ & EN 14108 & - & 5 & $\mathrm{mg} / \mathrm{kg}$ \\
\hline Metals I (Ca+Mg) & EN 14538 & - & 5 & $\mathrm{mg} / \mathrm{kg}$ \\
\hline
\end{tabular}

\section{Small-scale mobile production of biodiesel}

\subsection{Batch system}

\subsubsection{Case 1: Standard mobile biodiesel unit}

Oliveira et al. (2009) and Brasil (2011) constructed a mobile biodiesel production unit (Fig. 1) comprising a reactor equipped with a stirrer, a separation tank, and a distillation unit for biodiesel refining. The unit is typically mounted on a truck and conveyed from one local sources to another. The produced biodiesel is used by the local people that provides the oil source. The constructed unit was working well with an estimated production capacity of 0.19 ton/yr.

The unit is also equipped with a small laboratory facility located in the rear end of the unit to quickly check the quality of the biodiesel using analytical techniques such as near-infrared spectroscopy. Oliveira et al. (2009) highlighted that the advantages of such unit are: (i) low-capital investments (ii) lowering the use of fossil fuels, (iii) electricity needs can be provided by a generator that runs on biodiesel, and (iv) the unit can be operated by the local villagers without relying on highly competent operators. The biodiesel produced by the mobile unit had an ester conversion of $90-97 \%$ and with a purity of $98-99 \%$.

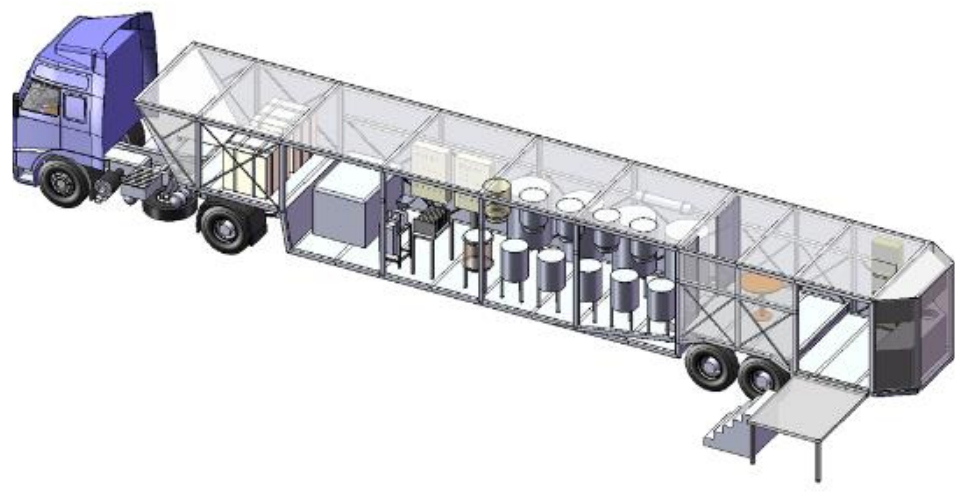

Fig. 1. Mobil biodiesel production unit designed by Oliveira et al. (2009)

Baum and Kelly (2009) also invented a mobile biodiesel manufacturing plant using vegetable oil and methanol as input. The mobile plant is made up of: (i) an oil expeller for mulching raw feedstock to extract oil from the feedstock, (ii) a mixer/reaction 
vessel in which the raw oil is mixed with a catalyst material, and (iii) at least one separation unit to separate methyl ester from other products. These units are incorporated in a self-contained shipping container containing a power generation means. The mobile unit has an estimated production capacity of $0.35-0.47$ ton/yr.

The mobile plant also includes a power generation means, i.e., a diesel generating set or a diesel power pack. Typically, the power generation means produces hydraulic power or electricity, which then powers the other process components. The power generation means is preferably fully enclosed within a separate compartment in the container. The invention claimed that it can take most oilbearing crops and produces biodiesel that satisfies the international specification which can go straight into the tank of any diesel engine without any modification (Baum and Kelly, 2009).

Bhachu et al. (2005) designed a portable biodiesel system capable of processing different grades of waste cooking oil (WCO) to produce biodiesel. The biodiesel plant is separated into five sections, viz.: (i) reactant preparation, (ii) pre-treatment, (iii) transesterification, (iv) purification, (v) solvent recovery and product storage. These sections are incorporated into a standard truck-trailer 8 -ft wide by $40-\mathrm{ft}$ long by $9.5-\mathrm{ft}$ tall. The plant can be conveyed to the storage location of the feedstock, particularly small community areas, where it will process the feedstock into biodiesel. The biodiesel is then stored locally to facilitate redistribution in the community. The estimated capacity of the mobile unit is 0.14 ton/yr.

\subsubsection{Case 2: Integrated rendering facility and biodiesel refinery}

Mullard (2007) patented a mobile animal waste recycling and biodiesel production system. The system is made up of an integrated rendering facility and biodiesel refinery contained in a $70 \mathrm{~m}^{3}$ refrigerated shipping container attached to a trailer. The unit is fully transportable, allowing it to travel to different locations to collect animal waste and process it into biodiesel. The rendering facility takes animal waste as input and separates the oils and fats that are valorised as an input to produce biodiesel. The produced biodiesel is used as fuel to power both the rendering facility and the biodiesel refinery and may also be used to fuel the semi-trailer vehicle.

Typically, the animal waste was crushed into pieces of around $5 \mathrm{~mm}$, before being liquefied with suitable enzymes at $40-55^{\circ} \mathrm{C}$. The liquefied material was then mechanically separated by a centrifuge into the water, fats/oil, and fine solid phases. The oil was then filtered using a removable strainer and cloth with a suitable mesh size to remove any contaminants. The filtered oil was transferred to a cylindrical propane reactor. The housing was equipped with a zeolite ozone bio-filter to absorb noxious odours that might have persisted even after the recycling of the organic waste (Mullard, 2007).

The oil in the reactor was heated to approximately $80-90{ }^{\circ} \mathrm{C}$. After the pressure in the reactor was reduced to $0.5 \mathrm{psi}$, a vacuum unit was used to remove water from the oil. The pressure was held constant until no more water collected in the liquid trap. The oil was allowed to cool to about $50^{\circ} \mathrm{C}$ and then mixed with methoxide. The mixture was heated using an immersion heater and circulated for about an hour, and then allowed to settle. After approximately $12 \mathrm{~h}$, glycerol was drained from the bottom of the reactor. The remaining oil in the reactor was reheated to about $50^{\circ} \mathrm{C}$ and mixed again with methoxide. The mixture was heated using an immersion heater and circulated for approximately $1 \mathrm{~h}$, and then allowed to settle. After approximately $12 \mathrm{~h}$, the newly formed glycerol was drained from the bottom of the reactor. The biodiesel was conveyed to a washing unit for bubble washing for at least $12 \mathrm{~h}$ and then allowed to settle. After that, the remaining water left in the tank was drained. The biodiesel was passed through a filter to remove any impurities (Mullard, 2007).

\subsection{Continuous system}

\subsubsection{Case 1: Continuous nozzle jet separation reactor}

Teall and Sickels (2005) patented a system and methods for modular production of biodiesel using new or recycled oil. The system consists of a mixing unit, a reaction unit, a separation unit, a distillation unit, and a filtering unit. These units are incorporated into a single housing such as a standard shipping container that can easily be transported to a remote city by a truck. The mobile unit has an estimated production capacity of 3.4-10.2 ton/yr (Teall and Sickels, 2005).

The modular production unit had additionally fixed and/or relocatable units to serve as a biodiesel processing system. The unit was also equipped with a processing system for raw materials, which included a hot box for filtration and separation of waste and residue from recycled triglyceride input. The hot box roller barrel was also used to introduce heat to the raw or recycled oil feedstock. The processing of the refined biodiesel involved filtration and separation to reduce the moisture content in accordance with the biodiesel specification. This modular unit has an estimated production capacity of about 3.4-10.2 ton/yr (Teall and Sickels, 2005).

\subsubsection{Case 2: Computer-controlled separator filtration and catalysing vessel}

Patten (2005) patented a computer-controlled and automated mobile production of biodiesel using waste cooking oil (WCO). WCO was typically collected at dispersed locations and sent to large refineries at centralized locations for processing and conversion to biodiesel. However, such systems were inherently less efficient than mobile processing facilities. Patten invented a method and apparatus for reclaiming spent oil using a strainer/separator filtration process and catalyst media, contained in a mobile enclosure such as a truck.

The mobile refinery was used at various collection sites for WCO cleaning and conversion into biodiesel. Upon collection, the oil was passed through a strainer/separator filtration process to remove particulate contaminants and water. The oil was then heated and conveyed to a catalysing vessel, which was able to titrate a proper amount of catalyst; the vessel also monitored and removed the accumulated glycerol. The produced biodiesel was conveyed to a washing vessel to remove any remaining impurities while also monitoring and balancing the $\mathrm{pH}$ of the biodiesel. After refining, the biodiesel was transported to a delivery tank (Patten, 2005).

Upon delivery, the biodiesel was filtered again, and the amount and specifications of the biodiesel were logged by a computer. In the case of failure, the driver was immediately noticed by the computer. The mobile refinery was then directed to the nearest service centre. This system allows for continuous online monitoring and may be checked via the internet. The advantage of this centralized regeneration is that the waste produced by filtration can be concentrated in a single treatment and disposal facility (Patten, 2005).

\subsubsection{Case 2: Computer-controlled separator filtration and catalysing vessel}

Keady (2008) patented a mobile processing plant that includes devices and methods for the automation of mobile biodiesel production from a feedstock oil. Typically, the oil was pumped into the mobile processing plant. A sample was taken from the oil by an automatic titration system to determine the FFA value of the oil and concentration of catalyst for the transesterification. The catalyst was then added to methanol and mixed with the oil in a porous mixing device to produce biodiesel. The oil passed through an interface containing sub-tubes which delivered the oil through the interface into the porous mixing block (Keady, 2008). 
The pressure of the fluid saturating the porous block can be varied to minimize oil absorption by the porous block while ensuring that the fluid in the porous block lining the tube surface enters the oil stream. The unreacted oil and glycerol can be separated from the biodiesel using a centrifugal separator. It comprises of a mixing region, a spin separating region and a flow separating region, with optional recycling loops that feedback into the system. The separated biodiesel can be washed with water in an additional cleansing unit comprising of several chambers connected by tubes (Keady, 2008).

\subsubsection{Case 4: Homogenization and separator reactor}

Rummer (2013) patented a compact biodiesel production system. It comprises of: (i) an oil expeller for crude oil extraction from the raw feedstock, (ii) a degumming process reactor for the removal of at least one of the gums, metal compounds and other impurities from the crude oil, (iii) a reactor and separator unit or vessel for transesterification of the crude oil to biodiesel and for glycerol removal from the methyl esters, (iv) a flash tank for methanol recovery, (v) a mixer and blending tank for the completion of the neutralization reaction, (vi) an ion-exchange purification vessel for the removal of residual glycerol, soaps, free fatty acids, unreacted oil, waxes, salts, water and methanol, (vii) a water separator, and (viii) a polishing filter to remove any remaining particulate impurities before the biodiesel exits the system into a collection tank. These units are incorporated in a standard 20-ft container for ease of relocatability (Rummer, 2013).

This system allows continuous transesterification of oil using methanol and $\mathrm{NaOH}$ as a catalyst, to produce biodiesel using a homogenization and separator reactor. The reactor consists of several chambers. In the first chamber of the reactor, oil is mixed with a stoichiometric amount of methanol-to-oil ratio and in the presence of a $2-10 \% \mathrm{w} \mathrm{NaOH}$ catalyst. In the second chamber, a coalescer is added to augment the separation of glycerol from the produced crude biodiesel. A drainage outlet is available at the bottom of the chamber for the removal of glycerol and other substances which are heavier than the crude biodiesel. In the third chamber, the crude biodiesel is reacted for a second time with about $8-15 \%$ of the amount of the biodiesel mixture containing a $2-10 \% \mathrm{w}$ $\mathrm{NaOH}$ catalyst. In the fourth chamber, residual glycerol is separated from the enriched crude biodiesel. The temperature of the process should be kept at about $60{ }^{\circ} \mathrm{C}$, and the pressure set slightly above the ambient pressure (Rummer, 2013).

\subsection{Comparison between community-scale and mobile production of biodiesel}

An overview of existing community-scale and mobile biodiesel production concepts and units are shown in Table 4. According to the data in Table 4, most of the feedstock are vegetable oil, except in some cases where non-edible oil and animal fats are used as input. Methanol is used in almost all cases except for the mobile biodiesel refinery invented by Patten (2005) and the mobile biodiesel concept proposed by Abduh et al. (2013).

Pre-treatment of the feedstock includes pre-heating, filtration, degumming, enzymatic treatment, and esterification. For an input with a high FFA content, esterification is applied to reduce the FFA below 3\% (Bhachu, 2005; Sarantopoulos et al., 2009). Automatic titration can also be applied to reduce the high FFA, as patented by Keady (2008). In the case of animal waste, enzymatic treatment is applied to liquefy the waste before transesterification. Filtration is typically applied to remove any contaminants that may be present in the oil (Patten, 2005; Baum and Kelly, 2009; Sarantopoulos et al. 2009; Brasil, 2011),

From Table 4, it can be seen that transesterification of triglycerides is performed either in batch or in a continuous setup. For batch transesterification, a stirred/mixing or cone-shaped tank is normally used. The temperature of the reactor is normally maintained at $50-65{ }^{\circ} \mathrm{C}$, except for the mobile manufacturing plant invented by Baum and Kelly (2009) which operates at $90{ }^{\circ} \mathrm{C}$. A homogenous catalyst $\left(\mathrm{NaOH} / \mathrm{KOH} / \mathrm{CH}_{3} \mathrm{ONa}\right)$ is normally used, and the reaction is performed for at least $1-1.5 \mathrm{~h}$.

Transesterification of oil or fat with alcohol produces a mixture of biodiesel and, glycerol as well as free fatty acid, di- and monoglycerides. In addition, unreacted alcohol, and catalyst also presence in the mixture that need to be removed. Refining of the biodiesel mixture is required to make that the biodiesel meets the international specifications (van Gerpen et al., 2004). Washing with water is typically applied for the refining process. Various studies have been conducted to increase the efficiency of the washing process including washing with distilled water $\left(50-80^{\circ} \mathrm{C}\right)$, dilution of the biodiesel mixture in petroleum ether followed by washing with water, neutralization with $\mathrm{H}_{2} \mathrm{SO}_{4}$ as well as two sequential steps of biodiesel washing using $\mathrm{NaCl}$ and $\mathrm{NaHCO}_{3}$ in water (Karaosmanoglu et al., 1999; Haas et al., 2003).

Refining of biodiesel by membrane separation and continuous centrifugal contactor separator has also been developed to reduce water usage (Abduh, 2015b; Wang et al., 2009; Gomes et al., 2013). Based on the existing studies, washing with water at $50{ }^{\circ} \mathrm{C}$ is considered the most suitable method community-scale stationary and mobile biodiesel plant (Karaosmanoglu et al., 1999). After washing, the biodiesel often has a relatively high-water content due to slight amounts of dissolved water and the presence of fine residual water droplets indicated by a slight cloudy exterior of the washed biodiesel. The high-water content in the biodiesel must be reduced to avoid microbial growth that can promotes hydrolysis of esters to form free fatty acids (Monteiro et al., 2008). There are various techniques to reduce the water content of crude biodiesel such as drying with hot air using a bubble column, vacuum driers and falling film evaporators (van Gerpen et al., 2004). However, spraying biodiesel with hot air is the most used method to reduce the water content of washed biodiesel in community-scale stationary and mobile biodiesel plant.

For a continuous setup, different types of reactor configurations can be applied, viz. continuous fixed bed (Monteiro et al., 2008), continuous centrifugal contactor separator (Tremblay et al., 2008; McNeff et al., 2008; Abduh et al., 2015; Abduh et al., 2016), automated catalysing vessel (Patten, 2005), homogenization and separator chamber (Rummer, 2013), continuous mixer (https://biocube.com), and cone-shaped tank with nozzle jet (Teall and Sickels, 2005). Alkali-catalytic transesterification is observed for all the continuous setup, except for the study conducted by McNeff et al. (2008), which used supercritical methanol at high temperature and pressure. The advantage of the so-called Mcgyan process (Fig. 2) is that the conversion rate is within seconds, and it can be used for a variety of feedstock. This process does not require a catalyst and does not produce glycerol as a major by-product. Hence, the post-treatment stage of purifying the biodiesel is relatively easy as compared to other systems that require the separation of the remnants of the catalyst and the by-product glycerol.

\section{Future perspective for mobile production of biodiesel}

\subsection{Continuous centrifugal contactor separator}

A continuous centrifugal contactor separator (CCCS) is a compact device that integrates several processes particularly mixing, reaction, and separation of liquid-liquid systems; thus, it demonstrates process intensification in an interesting way. The CCCS consists of a hollow, rotating centrifuge placed inside a static reactor housing. In a typical biodiesel production process, plant oil and alcohol are pumped into the CCCS and intensely mixed in the annular zone which is located between the static housing and the 
rotating centrifuge. Due to rotation, the mixture is pushed into the hollow centrifuge through a hole at the bottom of the centrifuge. Inside the centrifugal zone, biodiesel and glycerol are separated by centrifugal forces which depends on the applied rotational speed. The centrifugal force can be set up to $900 \mathrm{~g}$ to ensure excellent separation of a liquid mixture having different densities (Kraai et al., 2008; Kraai et al., 2009; Abduh et al., 2015; Abduh et al., 2016).

Abduh et al. (2015) has carried out a continuous synthesis and refining of biodiesel in a cascade of two CCCS devices in a laboratory scale with an estimated production capacity of 6.6 ton/yr. The synthesised biodiesel was characterised and most of the properties such as ester and glycerol content, acid value and water content meet the ASTM specifications. As such highlights the potential of CCCS to be used in the design of a mobile biodiesel unit due to its compact size and flexibility in operation as well as robustness and high volumetric productivity.

\subsection{Continuous fixed bed with supercritical methanol}

McNeff et al. (2008) developed a continuous fixed bed reactor to produce biodiesel using a metal oxide-based catalyst. It has been shown that porous metal oxides such as zirconia and alumina with different surface treatments particularly acid and base that are amenable to a fixed bed reactor are capable of continuous rapid esterification and transesterification simultaneously at high pressure $(2500 \mathrm{psi})$ and temperature $\left(300-450{ }^{\circ} \mathrm{C}\right)$. The so-called Mcygan process can be used with inexpensive feedstock such as animal fats, waste cooking oils and acidulated soap stock that has a high FFA content and different alcohol (methanol, n-propanol, nbutanol).

The process was tested for 25 different lipid feedstocks with an acid number ranging from $0.04-88 \mathrm{mg} \mathrm{KOH} / \mathrm{g}$ (molar ratio of methanol to oil was varied from 32.7 to 73.7 ). The system reached a steady-state after approximately 30 minutes, with an $86-95 \%$ conversion achieved for the 25 different lipid feedstocks with residence time of the reactants between 5.4 to $56.9 \mathrm{~s}$. The process was scaled up by increasing the volume of reactor by 49 times to achieve an annual productivity of more than 40000 gallons/yr with a contact time of $56.9 \mathrm{~s}$. The reaction was carried continuously for more than $115 \mathrm{~h}$ at a reactor temperature of $360{ }^{\circ} \mathrm{C}$ using refined soybean oil and methanol as the feedstock with a molar ratio of 32.7. the reaction was catalysed using $80-\mu \mathrm{m}, 60-\AA$ unmodified titania.

The average percent conversion was $87.5 \%$. The system has an estimated production capacity of 0.14 ton/yr.

\subsection{Reactive distillation column}

Reactive distillation combines chemical reaction and product separations in a single fractional distillation apparatus (da Silva et al., 2010). Simultaneous separation of reactant and product shifts the equilibrium towards the product side, hence increasing the conversion and selectivity (Estrada-Villagrana et al., 2006; Tuchlenski et al., 2011; Kiss et al., 2012). Numerous studies have been undertaken to explore the production of biodiesel using a reactive distillation system (Sotoft et al., 2010; Mueanmas et al., 2010). He et al. (2006) developed a reactive distillation column for biodiesel production using canola oil and methanol. The feed was passed through an in-line static mixer, which served as a prereactor, and entered the reactive distillation column near the top. The reactant mixture then flowed down across the plate. Methanol vapour obtained from the product mixture in the reboiler flowed upward to provide a uniform mixing in the column. The product mixture exited the reboiler to a glycerol-biodiesel separator. Here, the glycerol and biodiesel were continuously separated by gravitational force.

\subsection{Membrane reactor}

Various studies have been conducted to investigate simultaneous transesterification and separation using two-phase membrane reactor technology to synthesise high-quality biodiesel (Dubé et al., 2007; Cao et al., 2008a; Cao et al., 2008b; Badenes et al., 2011; Baroutian et al., 2011). This reactor allows reaction and separation to occur in one chamber and make certain that reversible transesterification favours the formation of biodiesel by removing the products simultaneously from the reactants, hence increasing the rate of reaction and yield of biodiesel (Armor et al., 1998; Sirkar et al., 1999). The application of a continuous membrane reactor using various oils with different FFA values, such as canola oil, hydrogenated palm oil and brown grease to produce biodiesel was studied by Cao et al. (2008a). Successful transesterification was observed for all the investigated feedstock and the produced biodiesel satisfied the ASTM D6751 standard.

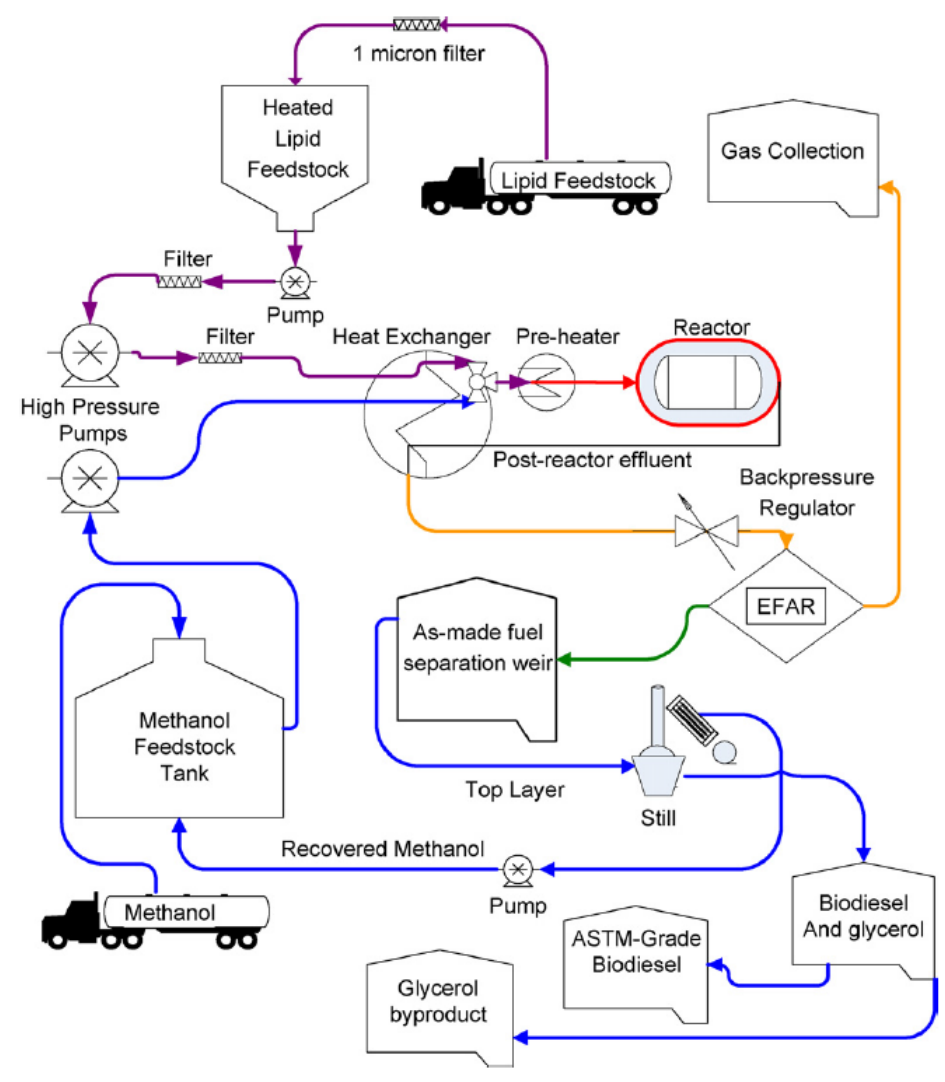

Fig 2. Process flow diagram of a biodiesel factory using the Mcgyan process proposed by McNeff et al. (2008)

\subsection{Ultrasonic cavitation reactor}

Recently, ultrasound technology has been applied in the synthesis of biodiesel to provide the required activation energy for transesterification and mechanical energy for mixing. In a typical process, when a reaction mixture is irradiated with ultrasound, radicals are formed during a brief implosive collapse of bubbles that accelerate the chemical reaction in the bulk medium. The radial motion of the bubbles generates micro-turbulence and brings about intense mixing of the immiscible reactant. Hence, the interfacial region between oil and alcohol increases intensively, which results in faster reaction kinetics, shorter reaction time and higher biodiesel yield (Stavarache et al., 2003; Colucci et al., 2005; Stavarache et al., 2006; Armenta et al., 2007; Deshmane et al., 2008; Kalva et al., 2009; Hanh et al., 2009). 
Table 4. Existing community scale and mobile biodiesel production concepts and unit

\begin{tabular}{|c|c|c|c|c|c|c|}
\hline Feedstock & Catalyst & Pre-treatment & Reactor & Post-treatment & $\begin{array}{l}\text { Capacity } \\
\text { (ton/yr) }\end{array}$ & Ref. \\
\hline $\begin{array}{l}\text { WCO ( } 6: 1 \text { molar ratio } \\
\text { methanol: oil) }\end{array}$ & $0.5 \% \mathrm{w} \mathrm{NaOH}$ & $\begin{array}{l}\text { Esterification }\left(\mathrm{H}_{2} \mathrm{SO}_{4}\right) \text {, filter, } \\
\text { heating }\left(65^{\circ} \mathrm{C}\right)\end{array}$ & Stirred tank $\left(65^{\circ} \mathrm{C}\right)$ & $\begin{array}{l}\text { Hydrocyclone, distillation, } \\
\text { neutralization, extraction }\end{array}$ & 0.14 & Bhachu et al. (2005) \\
\hline $\begin{array}{l}\text { Jatropha/karanj ( } 20 \% \\
\text { methanol) }\end{array}$ & $\begin{array}{l}0.5-1 \% \mathrm{w} \mathrm{NaOH} / \\
\mathrm{KOH}\end{array}$ & Heating $\left(100^{\circ} \mathrm{C}\right)$ & $\begin{array}{l}\text { Stirred tank }\left(60^{\circ} \mathrm{C}, 700 \mathrm{rpm}, 90 \%\right. \\
\text { yield after } 1.5 \mathrm{~h})\end{array}$ & Settling $(8 \mathrm{~h})$, bubble washing ( $8-24 \mathrm{~h})$ & $0.02^{\mathrm{a}}$ & Kalbande et al. (2008) \\
\hline $\begin{array}{l}\text { Pork fat (28\%v methanol } \\
\text { to fat) }\end{array}$ & $0.4 \% \mathrm{w} / \mathrm{v} \mathrm{NaOH}$ & Filtration & $\begin{array}{l}\text { Stirred tank }\left(65^{\circ} \mathrm{C}, 290 \mathrm{rpm}, 89 \%\right. \\
\text { yield after } 1.5 \mathrm{~h})\end{array}$ & $\begin{array}{l}\text { Settling }(2 \mathrm{~h}) \text {, water washing, heating } \\
\left(100^{\circ} \mathrm{C}, 10 \mathrm{~min}\right)\end{array}$ & 0.03 & Phalakornkule et al. (2009) \\
\hline $\begin{array}{l}\text { Soybean/WCO (6:1 molar } \\
\text { ratio ethanol: oil) }\end{array}$ & $1 \% \mathrm{w} \mathrm{CH}_{3} \mathrm{ONa}$ & Filtration & $\begin{array}{l}\text { Stirred tank }\left(55^{\circ} \mathrm{C}, 90-97 \% \text { yield after }\right. \\
1-1.5 \mathrm{~h})\end{array}$ & $\begin{array}{l}\text { Settling }(1 \mathrm{~h}) \text {, water washing, } \\
\text { distillation }\end{array}$ & 0.19 & Oliveira et al. (2009) \\
\hline Vegetable oil (methanol) & $\mathrm{NaOH} / \mathrm{KOH}$ & $\begin{array}{l}\text { Settling, } \\
\text { Heating }\left(45^{\circ} \mathrm{C}\right)\end{array}$ & Mixing tank $\left(90^{\circ} \mathrm{C}\right)$ & Settling, evaporation, Filtration & $\begin{array}{l}0.35- \\
0.47\end{array}$ & Baum and Kelly (2009) \\
\hline $\begin{array}{l}\text { Palm oil ( } 6: 1 \text { molar ratio } \\
\text { methanol: oil) }\end{array}$ & $1 \% w / v \mathrm{NaOH}$ & $\begin{array}{l}\text { Esterification } \\
\left(\mathrm{H}_{2} \mathrm{SO}_{4}\right)\end{array}$ & Cone-shaped tank $\left(55^{\circ} \mathrm{C}, 1 \mathrm{~h}\right)$ & Settling, water washing, drying (12 h) & 0.14 & Sarantopoulos et al. (2009) \\
\hline Animal waste (methanol) & Methoxide & $\begin{array}{l}\text { Grinding, enzymatic treatment, } \\
\text { heating, centrifugation }\end{array}$ & $\begin{array}{l}\text { Cylindrical tank (two-steps } \\
\text { transesterification, } 0.5 \mathrm{psi}, 50^{\circ} \mathrm{C}, 12 \mathrm{~h} \text { ) }\end{array}$ & $\begin{array}{l}\text { Separation, bubble washing (12), } \\
\text { filtration }\end{array}$ & $\mathrm{n} / \mathrm{a}$ & Mullard (2007) \\
\hline $\begin{array}{l}\text { Soybean oil ( } 32.7 \text { molar } \\
\text { ratio methanol: oil) }\end{array}$ & $\begin{array}{l}\mathrm{TiO}_{2}(80 \\
\mu \mathrm{m}, 60 \AA)\end{array}$ & $\begin{array}{l}\text { Filtration Heating } \\
\left(360^{\circ} \mathrm{C}\right)\end{array}$ & $\begin{array}{l}\text { Continuous fixed bed ( } 360 \mathrm{C}, 2500 \mathrm{psi} \text {, } \\
87.5 \% \text { yield after } 56.9 \mathrm{~s} \text { ) }\end{array}$ & E-FAR system (alumina packed bed) & 0.14 & McNeff et al. (2008) \\
\hline $\begin{array}{l}\text { Sunflower ( } 6: 1 \text { molar } \\
\text { ratio methanol: oil) }\end{array}$ & $1 \% \mathrm{w} \mathrm{NaOMe}$ & Pre-heat to $60^{\circ} \mathrm{C}$ & $\begin{array}{l}\text { Continuous centrifugal contactor } \\
\text { separator }\end{array}$ & $\mathrm{n} / \mathrm{a}$ & 5.6 & Kraai et al. (2009) \\
\hline $\begin{array}{l}\text { Jatropha ( } 6: 1 \text { molar ratio } \\
\text { ethanol: oil) }\end{array}$ & 1\%w NaOEt & Pre-heat to $60^{\circ} \mathrm{C}$ & $\begin{array}{l}\text { Continuous centrifugal contactor } \\
\text { separator }\end{array}$ & $\mathrm{n} / \mathrm{a}$ & 10.1 & Abduh et al. (2013) \\
\hline $\begin{array}{l}\text { Sunflower (6:1 molar } \\
\text { ratio methanol: oil) }\end{array}$ & $1 \% \mathrm{w} \mathrm{NaOMe}$ & Pre-heat to $60^{\circ} \mathrm{C}$ & $\begin{array}{l}\text { Continuous centrifugal contactor } \\
\text { separator }\end{array}$ & Water washing, drying & 6.6 & Abduh et al. (2015) \\
\hline $\begin{array}{l}\text { New/recycled oil } \\
\text { (ethanol) }\end{array}$ & $\mathrm{NaOH}$ & Hot box roller barrel & $\begin{array}{l}\text { Cone-shaped tank with nozzle jet (65 } \\
{ }^{\circ} \mathrm{C} \text { ) }\end{array}$ & Centrifugation, distillation & $3.4-10.2$ & Teall and Sickels (2005) \\
\hline $\begin{array}{l}\text { Vegetable oil } \\
\text { (methanol/ethanol) }\end{array}$ & $\mathrm{NaOH} / \mathrm{KOH}$ & Vacuum filtration, heating & $\begin{array}{l}\text { Automated catalysing } \\
\text { Vessel }\end{array}$ & Separation, washing, filtration & $\mathrm{n} / \mathrm{a}$ & Patten (2005) \\
\hline Vegetable oil, (methanol) & $\mathrm{NaOH}$ & Automated titration & Porous mixing device & Spin separator & $\mathrm{n} / \mathrm{a}$ & Keady (2008) \\
\hline Vegetable oil, (methanol) & $2-10 \% \mathrm{w} \mathrm{NaOH}$ & Degumming & $\begin{array}{l}\text { Homogenisation and separator chamber } \\
\left(55^{\circ} \mathrm{C}\right)\end{array}$ & $\begin{array}{l}\text { Settling, neutralization, evaporation, } \\
\text { filtration }\end{array}$ & $\mathrm{n} / \mathrm{a}$ & Rummer (2013) \\
\hline
\end{tabular}

a) estimated assuming $330 \mathrm{~d} / \mathrm{yr}$ 
Transesterification of plant oils using low-frequency ultrasound $(28-40 \mathrm{kHz})$ has been investigated by Stavarache et al. (2006) and obtained an excellent yield of $98 \%$ for the $28 \mathrm{kHz}$ ultrasound and the reaction time greatly reduced at $40 \mathrm{kHz}$ (Stavarache et al., 2006). In another study, it was hypothesized that when low ultrasonic waves $(20 \mathrm{kHz})$ are applied to a two-phase reaction system, the mass transfer and kinetic rate would be enhanced by an increase in the interfacial area and activity of the formed microscopic and macroscopic bubbles in the system (Colucci et al., 2005).

\subsection{Alcohol recovery}

Conventional production of biodiesel involves transesterification of plant oil with methanol in the presence of an appropriate catalyst (Bender, 1999; Bernesson et al., 2004; Oliveira et al., 2009; Brasil, 2011). Typically, a 6:1 methanol-to-oil molar ratio is used for alkali- and acid-catalytic methods, whereas for the supercritical method, this ratio can be up to 32:1. Excess alcohol is commonly added to shift the equilibrium to the product site. In addition, the excess quantity of alcohol hastens the conversion of triglycerides into biodiesel (Schwab et al., 1987; Fukuda et al., 2001; Forson et al., 2004; Helwani et al., 2009; Al-Zuhair, 2007). The excess alcohol is often distributed in the mixture of biodiesel and glycerol phases. According to the biodiesel specifications (Table 3 ), the maximum amount of methanol in biodiesel is $0.2 \% \mathrm{w} / \mathrm{w}$. The excess methanol in the by-product glycerol should be separated to improve the commercial value of the glycerol. Hence, the excess alcohol must be removed from both the biodiesel and glycerol phases. Typically, alcohol recovery involves using a distillation column. It is expected that $60 \%$ of the excess methanol could be recovered, and the recycled alcohol can be reused, thereby reducing the amount of fresh methanol needed for subsequent transesterification reactions and consequently lowering the operational cost (Abduh et al., 2015).

Studies on alcohol recovery in the production of biodiesel have been previously investigated. Mythili et al. (2014) investigated methanol recovery using a methanol vaporization reactor during production of biodiesel using Jatropha oil. They reported that 2.3\% of methanol was recovered from the biodiesel phase, whereas $27.4 \%$ of methanol was recovered from the glycerol phase. Canacki et al. (2003) investigated the recovery of methanol from biodiesel produced from soybean oil, yellow grease and brown grease using a distillation setup. Xie et al. (2011) reported that $85.8 \%$ of methanol in glycerine could be recovered by coagulation.

Several patents on mobile biodiesel unit briefly explain the alcohol recovery section used in each mobile unit. Rummer (2013) used an integral methanol extraction/recovery system to recover the excess methanol, whereas Brasil (2011) used an evaporation column to recover the excess alcohol. Teall and Sickels (2005) reported that a continuous flow distillation unit was used to recover the excess alcohol. Baum and Kelly (2009) used a methanol separation system which consists of a flash tank and a condensation column. All the patents claimed that their invention proved to be safe despite of transporting alcohol and able to reach diverse location with safety, durability while ensuring the quality of the produced biodiesel. Safety features of the mobile units include an emergency exit and fire extinguisher at the back end of the unit (Oliveira et al., 2009).

Dhar and Kirtania (2009) carried out a simulation study using Aspen Plus software to investigate the recovery of excess methanol in a biodiesel production process. A distillation column was introduced before the phase separation to recover alcohol from both the biodiesel and glycerol phases. The simulation results showed that at certain operating conditions, approximately $95-98 \%$ of excess methanol could be recovered. In another simulation study, Abduh et al. (2016) developed a refining model that includes a methanol and water recovery section, with the objective to minimize methanol and water consumption in the refining process. It was reported that approximately $97 \%$ of excess methanol could be recovered and recycled to further synthesize biodiesel (Abduh et al., 2016).

\section{Production cost of biodiesel}

\subsection{Conventional production of biodiesel}

The production cost of biodiesel fuels varies depending on the raw materials, geographical location, variability in crop production from season to season and the price of crude petroleum (Kralova et al., 2010). In addition, types of pre-treatment, operating life of the plant, performance efficiencies, and future timing of the commercial availability of both the feedstock supply chain and conversion technologies also influence the total production cost (Sims et al., 2010; Abduh et al., 2019). The cost of transportation and distribution of biodiesel particularly to remote markets also add to the total biodiesel production cost (Agarwal, 2007).

Abduh et al. (2017) reported that the production cost of rubber seed oil and rubber seed biodiesel in a small-scale (55 ton/yr) biodiesel production system in Palangkaraya, Indonesia were estimated at $\$ 0.42 / 1$ and $\$ 1.12 / 1$, respectively. The estimated cost is slightly lower than the price of diesel in remote areas close to the investigated area (up to $\$ 1.41 / 1$ ). The study reported that the production cost is highly influenced by the production capacity whereas the capital investment has a relatively minor influence on the production cost of the oil and biodiesel.

Table 5 Investment and production cost for small scale production of biodiesel

\begin{tabular}{llllll}
\hline Feedstock & Capacity (ton/yr) & Investment cost $(\mathbf{k}$ ) & Production cost $\mathbf{( \$ / )}$ & Payback period (yr) & Ref. \\
\hline Pork fat & 0.03 & 4.1 & 0.84 & 1.66 & Phalakornkule et al. (2009) \\
Soybean oil & 0.14 & - & 0.76 & - & McNeff et al. (2008) \\
Soybean oil/WCO & 0.19 & 112 & - & 14.4 & Oliveira et al. (2009) \\
WCO & 0.14 & 300 & 1.92 & - & Bhachu et al. (2005) \\
Rubber seed oil & 55 & 133 & Abduh et al. (2017b) \\
\hline
\end{tabular}

Agarwal (2007) reported that the biodiesel production cost before tax is approximately $120-175 \%$ more expensive than the mineral diesel. The cost of biodiesel from vegetable oil is estimated in the range of \$0.54-1.3/1 (Agarwal, 2007; Sims et al., 2010) whereas the production cost of biodiesel using enzyme and microalgae is estimated to be in the range of be $\$ 0.87-1.78 / 1$ (Stavarache et al., 2003) and \$2.4/1 (Janaun and Ellis, 2010), respectively.
The biodiesel cost can be lowered if non-edible oils are considered instead of edible oils. Non-edible oils such jatropha and rubber seeds are readily available in certain countries at lower prices in comparison to edible oils. Most of the non-edible oils are currently not yet valorised and regarded as waste. It is reported that the estimated costs for biodiesel from non-edible oil seed is in the range of $\$ 0.30-0.69 / 1$. This includes pressed cake and glycerol credits and assuming that the production facility added onto an 
existing grain or tallow facility to reduce the capital investment cost (Agarwal, 2007).

In countries like Netherlands, Germany, Belgium, Austria, USA, Japan, and India, WCO would be a good alternative because most of the frying oils are currently discarded. The WCO can be valorised to reduce the production cost of biodiesel and reduce the cost of water treatment in the sewerage system while promoting the recycling of resources (Sims et al., 2010). The cost of biodiesel from WCO lies in the range of \$0.34-0.42/1 (Agarwal, 2007).

According to Helwani et al. (2009), continuous production systems may attain higher throughput of biodiesel. This may reduce the production cost and lower the overall cost of biodiesel. Hence, the price for biodiesel in the market can be reduced. However, batch systems are less expensive to build and more flexible to the change of raw materials and reaction conditions. In this sense, small scale production of biodiesel particularly at remote areas may increase the economic viability of biodiesel in the market.

\subsection{Small scale production of biodiesel}

Table 5 shows the limited data currently available for the economic assessment of small-scale production of biodiesel. The investment cost for a community scale production of biodiesel from pork fat (0.03 ton/yr) in Thailand is approximately \$ 4100. It is reported that the production cost for this batch operation is $\$ 0.84 / 1$ with a payback period of 1.66 year (Phalakornkule et al., 2009). A slightly lower production cost of $\$ 0.76 / 1$ is reported for a continuous setup producing biodiesel using soybean oil and supercritical methanol with an estimated production capacity of 0.14 ton/yr (McNeff et al., 2008).

The investment cost for a mobile biodiesel unit capable of producing 0.19 ton/yr biodiesel from soybean oil or WCO is estimated at $\$ 112000$ (Oliveira et al., 2009; Brasil, 2011). This cost is lower than the investment cost of $\$ 300000$ reported by Bhachu et al. (2005). With a production capacity of 0.14 ton/yr, the mobile production unit has a payback period of 14.4 years at production cost of \$0.92/1. Abduh et al. (2017a) reported an investment cost of $\$ 133000$ for a 55 ton/yr production of biodiesel from rubber seed oil. The estimated production cost is $\$ 1.12 / 1$. From Table 5, it can be observed that the range of production is still not yet competitive to the current average price of approximately $\$ 0.98 / 1$ of diesel around the world.

The relatively high small scale production cost of biodiesel must be reduced to be economically feasible by considering local resources for local demand. The local resources must be carefully selected from biomass that are readily available in sufficient amount but are not yet utilized. The production capacity must be adjusted to fit the amount of available feedstock and local demand on order to minimize the logistic cost. Combination of carefully selected feedstock and simple technology that match the demand of the community may help to promote the economic feasibility of smallscale production of biodiesel.

The application of a biorefinery concept in the small-scale production of biodiesel that emphasizes on optimizing valorization of biomass, minimizing waste, and maximizing profit to achieve sustainable development (Abduh et al., 2017a) may be considered as a wise strategy to reduce the relatively high production cost of biodiesel. For the first aspect in a biorefinery concept, valorization of biomass in the biorefinery concept may include the use biomass that has not yet been utilized but readily available in abundance such as rubber seeds for the case of Indonesia that has the second largest rubber tree plantations in the world. The case of rubber seeds may also be applied for the second and third aspects of a biorefinery concept.

For the second aspect, minimizing waste may refer to the valorization of the outer shell of the rubber seeds that are typically removed prior to the isolation of oil from the dehulled rubber seeds.
Abduh et al. (2017b) has demonstrated that the shell may be used as one of the substrates for the cultivation of Hermetia illucens to produce protein and oil rich biomass. For the third aspect, maximizing profit may be attained by producing co-products apart from biodiesel and glycerol. The pressed cake obtained after the isolation of oil may be further valorized as cattle feed it still contains a relatively high amount of protein (Widyarani, 2014; Abduh et al., 2017b).

In another study, Kumar and Singh (2009) reported that process modifications and engineering advancement in microalgal biodiesel production, the biodiesel cost can be reduced from $\$ 4.92 / \mathrm{kg}$ to $\$ 0.50 / \mathrm{kg}$. The application of a biorefinery concept through coupling phycoremediation of pollution loads in the waste streams to microalgal biomass production results in economic advantage and environmental benefits. Hence, the application of a biorefinery concept for small scale of production of biodiesel particularly in the rural areas may translate into an economically alluring and environmentally attractive business model that may reduce the production cost and increase the welfare of the community.

\section{Conclusion}

Recent developments in community-scale, mobile production units of biodiesel have been reviewed in this paper. Currently, most of the feedstock used in community-scale mobile biodiesel units for producing biodiesel is based on vegetable oils, although in some cases, non-edible oils and animal fats are applied as input. Methanol is used in all cases, except for a very few cases where ethanol is used, as an alcohol input for transesterification. Pre-treatment of the feedstock such as pre-heating, filtration, degumming, enzymatic treatment, and esterification, is typically applied before transesterification. Transesterification of triglycerides is performed either in batch or in a continuous setup. For batch transesterification, a stirred/mixing or cone-shaped tank is normally used. The reaction temperature is normally set at 50-65 ${ }^{\circ} \mathrm{C}$. A homogenous catalyst is normally used, and the reaction lasts for at least $1-1.5 \mathrm{~h}$. The easiest post-treatments for product separation and purification include settling, water-washing, and drying. The methanol can be recovered from the product mixture by evaporation or distillation.

For a continuous setup, different types of reactor configurations are used such as continuous fixed bed, continuous centrifugal contactor separator, homogenization and separator chamber, and several others. Alkali-catalytic transesterification is normally applied for continuous transesterification of triglycerides to produce biodiesel. Supercritical methanol at a high temperature and pressure is also applied; its conversion rate is within seconds, and it can be used for a variety of feedstock. This process does not consume many catalysts and does not produce glycerol as a major by-product. Hence, the post-treatment stage of purifying the biodiesel is relatively easy compared to post-treatment in other systems that require separation of the remaining catalyst and the by-product glycerol. The production cost of biodiesel at a community scale varies from $\$ 0.76-1.12 / 1$. This range is still not yet competitive to the current average price of approximately $\$ 0.98 / 1$ of diesel around the world. The production cost may be reduced by applying a biorefinery concept that is economically attractive with an environmental benefit.

\section{Acknowledgement}

This work was financially supported by the Netherlands Organization for Scientific Research and Ministry of Research, Technology, and Higher Education Indonesia (PN-1-23-2018). 


\section{Conflict of interest}

No potential conflict of interest was reported by the authors.

\section{References}

Abduh MY. 2015. Biobased products from rubber, jatropha and sunflower oil. PhD Thesis. Groningen: University of Groningen

Abduh MY, Jamilah M, Istiandari P, Syaripudin, Manurung R. 2017a Bioconversion of rubber seeds to produce protein and oil-rich biomass using black soldier fly larva assisted by microbes. J Entomol Zool Stud 5(4): 591-7.

Abduh MY, Manurung R, Heeres HJ. 2017b. Techno-economic analysis for small scale production of rubber seed oil and biodiesel in Palangkaraya, Indonesia. $J$ Clean Energ Technol 5(4): 268-73. doi 10.18178/JOCET.2017.5.4.381

Abduh MY, Martinez AF, Kloekhorst A, Manurung R, Heeres HJ. 2016a Experimental and modelling studies on continuous synthesis and refining of biodiesel in a dedicated bench scale unit using continuous centrifugal contactor separator technology. E J Lipid Sci Tech 118(6): 938-948. doi: 10.1002/ejlt.201500113

Abduh MY, Nadia MH, Syaripudin, Manurung R, Putra RE. 2018. Factors affecting the bioconversion of Philippine tung seeds by black soldier fly larvae for the production of protein and oil-rich biomass. $J$ Asia-Pac Entomol 21(3): 836-42. doi: 10.1016/j.aspen.2018.06.007

Abduh MY, Rasrendra CB, Subroto E, Manurung R, Heeres HJ. 2016b. Experimental and modelling studies on the solvent assisted hydraulic pressing of dehulled rubber seeds. Ind Crop Prod 92(15): 67-76. doi: 10.1016/j.indcrop.2016.07.025

Abduh MY, Syaripudin, Putri LW, Manurung R. 2019. Effect of storage time on moisture content of Reutealis Trisperma seed and its effect on acid value of the isolated oil and produced biodiesel. Energ Rep 5: 1375-80. doi: 10.1016/j.egyr.2019.09.066

Abduh MY, van Ulden W, Kalpoe V, van de Bovenkamp HH, Manurung R, Heeres HJ. 2013. Biodiesel synthesis from Jatropha curcas L. oil and ethanol in a continuous centrifugal contactor separator. $E J$ Lipid $S c$ Tech 115(1): 123-31. doi: 10.1002/ejlt.201200173

Abduh MY, van Ulden W, van de Bovenkamp HH, Buntara T, Picchioni F, Manurung R, Heeres HJ. 2015. Synthesis and refining of sunflower biodiesel in a cascade of continuous centrifugal contactor separators. $E$ J Lipid Sci Tech 117(2): 242-254. doi: 10.1002/ejlt.201400206

About the Biocube. https://biocubeco.com/biocube/ (accessed on September 20, 2020)

Agarwal AK. 2007. Biofuels (alcohols and biodiesel) applications as fuels for internal combustion engines. Prog Energ Combust 33(3):233-271. doi 10.1016/j.pecs.2006.08.003

Al-Zuhair S. 2007. Production of biodiesel: possibilities and challenges. Biofuel Bioprod Bior 1(1): 57-66. doi: 10.1002/bbb.2

Armenta RE, Vinatoru M, Burja AM, Kralovec JA, Barrow CJ. 2007. Transesterification of fish oil to produce fatty acid ethyl esters using ultrasonic energy. $J$ Am Oil Chem Soc 84: 1045-52. doi: 10.1007/s11746-007-1129-2

Armor J. 1998. Applications of catalytic inorganic membrane reactors to refinery products. J Membrane Sci 147(2): 217-33. doi: 10.1016/S03767388(98)00124-0

ASTM D6751 - 20a. 2020. Standard Specification for Biodiesel Fuel Blend Stock (B100) for Middle Distillate Fuels. West Conshohocken, PA: ASTM International.

Atabani A, Silitonga A, Badruddin IA, Mahlia T, Masjuki H, Mekhilef S. 2012 A comprehensive review on biodiesel as an alternative energy resource and its characteristics. Renew Sust Energ Rev 16(4): 2070-93. doi: 10.1016/j.rser.2012.01.003

Atadashi I, Aroua M, Aziz AA. 2011. Biodiesel separation and purification: a review. Renew Energ 36(2): 437-43. doi: 10.1016/j.renene.2010.07.019

Badenes SM, Lemos F, Cabral J. 2011. Performance of a cutinase membrane reactor for the production of biodiesel in organic media. Biotechnology and Bioengineering 108(6): 1279-89. doi: 10.1002/bit.23054

Balat M. 2007. Production of biodiesel from vegetable oils: A survey. Energ Source Part A 29: 895-913. doi: 10.1080/00908310500283359

Balat M. 2011. Potential alternatives to edible oils for biodiesel productionA review of current work. Energ Convers Manage 52(2): 1479-92. doi: 10.1016/j.enconman.2010.10.011

Balat M, Balat H. 2010. Progress in biodiesel processing. Appl Energ 87(6): 1815-35. doi: 10.1016/j.apenergy.2010.01.012

Baroutian S, Aroua MK, Raman AAA, Sulaiman N. 2011. A packed bed membrane reactor for production of biodiesel using activated carbon supported catalyst. Bioresource Technol 102(2): 1095-102. doi: $10.1016 /$ j.biortech.2010.08.076

Baum L, Kelly S. 2009. A biodiesel manufacturing system and apparatus. Patent. WO 2009089591 A1.

Becker K. 1980. Critical operating problems of solvent extraction plants. Oil Mill Gaz 84: 20-4.

Bender M. 1999. Economic feasibility review for community-scale farmer cooperatives for biodiesel. Bioresource Technol 70(1): 81-7. doi: 10.1016/S0960-8524(99)00009-7
Bernesson S, Nilsson D, Hansson P. 2004. A limited LCA comparing largeand small-scale production of rape methyl ester (RME) under Swedish conditions. Biomass Bioenerg 26(6): 545-59. doi: 10.1016/j.biombioe.2003.10.003

Bhachu U, Chow N, Christensen A, Drew A, Ishkintana L, Lu J. 2005. The design of a portable biodiesel plant. Columbia: The University of British Columbia.

Brasil A.N. 2011. Self-sustainable mobile biodiesel production plant and method. Patent. US 20110167712 A1.

Canakci M, Sanli H. 2008. Biodiesel production from various feedstocks and their effects on the fuel properties. J Ind Microbiol Biotechnol 35(5): 431-41. doi: 10.1007/s10295-008-0337-6

Canacki M, Van Gerpen J. 2003. A pilot plant to produce biodiesel from high free fatty acid feedstocks. $A S A B E$ 46(4): 945-54. doi: $10.13031 / 2013.13949$

Cao P, Dubé MA, Tremblay AY. 2008a. High-purity fatty acid methyl ester production from canola, soybean, palm, and yellow grease lipids by means of a membrane reactor. Biomass Bioenerg 32(11): 1028-36. doi: 10.1016/j.biombioe.2008.01.020

Cao P, Dubé MA, Tremblay AY. 2008b. Methanol recycling in the production of biodiesel in a membrane reactor. Fuel 87(6): 825-33. doi: 10.1016/j.fuel.2007.05.048

Cao P, Tremblay AY, Dubé MA, Morse K. 2007. Effect of membrane pore size on the performance of a membrane reactor for biodiesel production. Ind Eng Chem Res 46(1): 52-8. doi: 10.1021/ie060555o

Chouhan A, Sarma A. 2011. Modern heterogeneous catalysts for biodiese production: a comprehensive review. Renew Sust Energ Rev 15(9): 4378-99. doi: 10.1016/j.rser.2011.07.112

Colucci JA, Borrero EE, Alape F. 2005. Biodiesel from an alkaline transesterification reaction of soybean oil using ultrasonic mixing. $J \mathrm{Am}$ Oil Chem Soc 82: 525-30. doi: 10.1007/s11746-005-1104-3

da Silva, Nívea de Lima, Santander CMG, Batistella CB, Maciel Filho R, Maciel MRW. 2010. Biodiesel production from integration between reaction and separation system: reactive distillation process. Appl Biochem Biotechnol 161(1-8): 245-54. doi: 10.1007/s12010-009-8882

Demirbas AH. 2003. Biodiesel fuels from vegetable oils via catalytic and non-catalytic supercritical alcohol transesterifications and other methods: a survey. Energ Convers Manage 44(13): 2093-109. doi: 10.1016/S0196-8904(02)00234-0

Demirbas AH, Demirbas I. 2007. Importance of rural bioenergy for developing countries. Energ Convers Manage 48(8): 2386-98. doi: 10.1016/j.enconman.2007.03.005

Deng X, Fang Z, Liu Y, Yu C. 2011. Production of biodiesel from Jatropha oil catalyzed by nanosized solid basic catalyst. Energy 36(2): 777-84. doi: $10.1016 /$ j.energy.2010.12.043

Deshmane VG, Gogate PR, Pandit AB. 2008. Ultrasound-assisted synthesis of biodiesel from palm fatty acid distillate. Ind Eng Chem Res 48(17): 7923-27. doi: 10.1021/ie800981v

Dhar BR, Kirtania K. 2009. Excess methanol recovery in biodiesel production process using a distillation column: a simulation study. Chem Eng Res Bull 13(2): 55-60. doi: 10.3329/cerb.v13i2.3538

Dubé M, Tremblay A, Liu J. 2007. Biodiesel production using a membrane reactor. Bioresource Technol 98(3): 639-47. doi: 10.1016/j.biortech.2006.02.019

Estrada-Villagrana A, Quiroz-Sosa G, Jiménez-Alarcón M, Alemán-Vázquez L, Cano-Domínguez J. 2006. Comparison between a conventional process and reactive distillation for naphtha hydrodesulfurization. Chem Eng Process 45(12): 1036-40. doi: 10.1016/j.cep.2006.03.019

European Standard for Biodiesel, EN 14214. Retrieved September 20, 2020 from https://www.intertek.com/biofuels/biodiesel/en-14214/

Forson F, Oduro E, Hammond-Donkoh E. 2004. Performance of jatropha oil blends in a diesel engine. Renew Energ 29(7): 1135-45. doi: 10.1016/j.renene.2003.11.002

Freedman B, Pryde E, Mounts T. 1984. Variables affecting the yields of fatty esters from transesterified vegetable oils. Journal of American Oil Chemist Society 61(10): 1638-43. doi: 10.1007/BF02541649

Fukuda H, Kondo A, Noda H. 2001. Biodiesel fuel production by transesterification of oils. $J$ Biosci Bioeng 92(5): 405-16. doi 10.1016/S1389-1723(01)80288-7

Gomes MCS, Arroyo PA, Pereira NC. 2013. Influence of acidified wate addition on the biodiesel and glycerol separation through membrane technology. $J$ Membrane Sci 431: 28-36. doi: 10.1016/j.memsci.2012.12.036

Haas MJ, McAloon AJ, Yee WC, Foglia TA. 2006. A process model to estimate biodiesel production costs. Bioresource Technol 97(4): 671-8. doi: 10.1016/j.biortech.2005.03.039

Haas MJ, Michalski PJ, Runyon S, Nunez A, Scott KM. 2003. Production of FAME from acid oil, a by-product of vegetable oil refining. $\mathrm{J} \mathrm{Am} \mathrm{Oil}$ Chem Soc 80: 97-102. doi: 10.1007/s11746-003-0658-4

Hanh HD, Dong NT, Okitsu K, Nishimura R, Maeda Y. 2009. Biodiesel production through transesterification of triolein with various alcohols in an ultrasonic field. Renew Energ 34(3): 766-8. doi: 10.1016/j.renene.2008.04.007 
He B, Singh A, Thompson J. 2006. A novel continuous-flow reactor using reactive distillation technique for biodiesel production. ASABE 49(1): 107-12. doi: 10.13031/2013.20218

Helwani Z, Othman M, Aziz N, Fernando W, Kim J. 2009. Technologies for production of biodiesel focusing on green catalytic techniques: a review. Fuel Process Technol 90(12): 1502-14. doi: 10.1016/j.fuproc.2009.07.016

Jain S, Sharma M. 2010. Biodiesel production from Jatropha curcas oil. Renew Sust Energ Rev 14(9): 3140-7. doi: 10.1016/j.rser.2010.07.047

Janaun J, Ellis N. 2010. Perspectives on biodiesel as a sustainable fuel Renew Sust Energ Rev14(4): 1312-20. doi: 10.1016/j.rser.2009.12.011

Jena PC, Raheman H, Prasanna Kumar G, Machavaram R. 2010. Biodiesel production from mixture of mahua and simarouba oils with high free fatty acids. Biomass Bioenerg 34(8): 1108-16. doi: 10.1016/j.biombioe.2010.02.019

Johnson L, Lusas E. 1983. Comparison of alternative solvents for oils extraction. J Am Oil Chem Soc 60: 229-42. doi: 10.1007/BF02543490

Kalbande S, More G, Nadre R. 2008. Biodiesel production from non-edible oils of jatropha and karanj for utilization in electrical generator. Bioenerg Res 1: 170-8. doi: 10.1007/s12155-008-9016-8

Kalva A, Sivasankar T, Moholkar VS. 2009. Physical mechanism of ultrasound-assisted synthesis of biodiesel. Ind Eng Chem Res 48(1): 534 44. doi: $10.1021 / \mathrm{ie} 800269 \mathrm{~g}$

Karaosmanoglu F, Cigizoglu KB, Tüter M, Ertekin S. 1996. Investigation of the refining step of biodiesel production. Energ Fuels 10(4): 890-5. doi: 10.1021/ef9502214

Karmakar A, Karmakar S, Mukherjee S. 2010. Properties of various plant and animal feedstocks for biodiesel production. Bioresource Technol 101(19): 7201-10.doi: 10.1016/j.biortech.2010.04.079

Keady JP. 2008. Devices and methods for automated mobile biodiesel production. Patent. US 20080105596 A1.

Khan L, Hanna M. 1983. Expression of oil from oilseeds-a review. $J A g r$ Eng Res 28(6): 495-503. doi: 10.1016/0021-8634(83)90113-0

Kiss AA, Segovia-Hernández JG, Bildea CS, Miranda-Galindo EY, Hernández S. 2012. Reactive DWC leading the way to FAME and fortune. Fuel 95: 352-9. doi: 10.1016/j.fuel.2011.12.064

Kraai G, Schuur B, Van Zwol F, Van de Bovenkamp H, Heeres H. 2009. Novel highly integrated biodiesel production technology in a centrifugal contactor separator device. Chem Eng $J$ 154(1-3): 384-9. doi: 10.1016/j.cej.2009.04.047

Kraai GN, van Zwol F, Schuur B, Heeres HJ, de Vries JG. 2008. Two-phase (bio) catalytic reactions in a table-top centrifugal contact separator. Angew Chem Int Ed Engl 47(21): 3905-8. doi: 10.1002/anie.200705426

Kralova I, Sjöblom J. 2010. Biofuels-renewable energy sources: a review. $J$ Disper Sci Technol 31(3): 409-25. doi: 10.1080/01932690903119674

Kumar D, Singh B. 2019. Algal biorefinery: An integrated approach for sustainable biodiesel production. Biomass Bioenerg 131: 105398. doi: 10.1016/j.biombioe.2019.105398

Lin L, Cunshan Z, Vittayapadung S, Xiangqian S, Mingdong D. 2011 Opportunities and challenges for biodiesel fuel. Appl Energ 88(4): 1020 31. doi: 10.1016/j.apenergy.2010.09.029

Ma F, Hanna MA. 1999. Biodiesel production: a review. Bioresource Technol 70(1): 1-15. doi: 10.1016/S0960-8524(99)00025-5

Marchetti J, Miguel V, Errazu A. 2007. Possible methods for biodiesel production. Renew Sust Energ Rev 11(6): 1300-11. doi: 10.1016/j.rser.2005.08.006

Martin Mittelbach. Biodiesel Production Technologies. http://www.co2star.eu/events/Mittelbach.pdf (retrieved 3 July 2020).

McNeff CV, McNeff LC, Yan B, Nowlan DT, Rasmussen M, Gyberg AE, Krohn BJ, Fedie RL, Hoye, TR. 2008. A continuous catalytic system for biodiesel production. Appl Catal A-Gen; 343(1-2): 39-48. doi: 10.1016/j.apcata.2008.03.019

Meher L, Vidya Sagar D, Naik S. 2006. Technical aspects of biodiesel production by transesterification - a review. Renew Sust Energ ReV 10(3): 248-68. doi: 10.1016/j.rser.2004.09.002

Mishra VK, Goswami R. 2018. A review of production, properties and advantages of biodiesel. Biofuels 9(2): 273-289. doi 10.1080/17597269.2017.1336350

Monteiro MR, Ambrozin ARP, Lião LM, Ferreira AG. 2008. Critical review on analytical methods for biodiesel characterization. Talanta 77(2): 593-605. doi: 10.1016/j.talanta.2008.07.001

Mueanmas C, Prasertsit K, Tongurai C. 2010. Feasibility study of reactive distillation column for transesterification of palm oils. Int $J$ Chem Eng Appl 1: 2010-21. doi: 10.7763/IJCEA.2010.V1.13

Mullard P. 2007. Mobile recycling and bio-fuel production system for animal waste. Patent. WO 2007033425 A1.

Mythili R, Venkatchalam P, Subramanian P, Uma D. 2014. Recovery of side streams in biodiesel production process. Fuel 117(Part A): 103-8. doi 10.1016/j.fuel.2013.09.008

Oh PP, Lau HLN, Chen J, Chong MF, Choo YM. 2012. A review on conventional technologies and emerging process intensification (PI) methods for biodiesel production. Renew Sust Energ Rev 16(7): 513145. doi: 10.1016/j.rser.2012.05.014

Oliveira LS, Brasil AN, Nunes DL. 2009. Design and operation of a mobile biodiesel production unit. Proceeding of the 2009 International
Conference on Chemical, Biological and Environmental Engineering 2932.

Patten JP. 2005. Mobile biodiesel refinery. Patent. US 20050006290 A1.

Phalakornkule C, Petiruksakul A, Puthavithi W. 2009. Biodiesel production in a small community: Case study in Thailand. Resour Conserv Recy 53(3): 129-35. doi: 10.1016/j.resconrec.2008.10.001

Ragit S, Mohapatra S, Kundu K, Gill P. 2011. Optimization of neem methyl ester from transesterification process and fuel characterization as a diesel substitute. Biomass Bioenerg 35(3): 1138-44. doi 10.1016/j.biombioe.2010.12.004

Robles-Medina A, González-Moreno P, Esteban-Cerdán L, Molina-Grima E. 2009. Biocatalysis: towards ever greener biodiesel production. Biotechnol Advan 27: 398-408. doi:

Rummer T. 2013. Mobile biodiesel production system. Patent. WO 2013007394.

Sarantopoulos I, Che F, Tsoutsos T, Bakirtzoglou V, Azangue W, Bienvenue D, Ndipen FM. 2009. An evaluation of a small-scale biodiesel production technology: Case study of Mango'o village, Center province, Cameroon. Phys Chem Earth $P T$ A/B/C 34(1-2): 55-8. doi: 10.1016/j.pce.2008.07.005

Sarin A, Arora R, Singh N, Sarin R, Malhotra R, Kundu K. 2009. Effect of blends of Palm-Jatropha-Pongamia biodiesels on cloud point and pour point. Energy 34(11): 2016-21. doi: 10.1016/j.energy.2009.08.017

Sarin R, Sharma M, Sinharay S, Malhotra R. 2007. Jatropha-palm biodiesel blends: an optimum mix for Asia. Fuel 86(10-11): 1365-71. doi: 10.1016/j.fuel.2006.11.040

Schwab A, Bagby M, Freedman B. 1987. Preparation and properties of diesel fuels from vegetable oils. Fuel 66(10): 1372-8. doi: 10.1016/00162361(87)90184-0

Shahid EM, Jamal Y. 2011. Production of biodiesel: a technical review. Renew Sust Energ Rev 15(9): 4732-45. doi: 10.1016/j.rser.2011.07.079

Sharma Y, Singh B. 2009. Development of biodiesel: current scenario. Renew Sust Energ Rev 13(6-7): 1646-51. doi: 10.1016/j.rser.2008.08.009

Sharma Y, Singh B, Upadhyay S. 2008. Advancements in development and characterization of biodiesel: a review. Fuel 87(12): 2355-73. doi: 10.1016/j.fuel.2008.01.014

Silitonga A, Atabani A, Mahlia T, Masjuki H, Badruddin IA, Mekhilef S. 2011. A review on prospect of Jatropha curcas for biodiesel in Indonesia. Renew Sust Energ Rev 15(8) :3733-56. doi: 10.1016/j.rser.2011.07.011

Sims RE, Mabee W, Saddler JN, Taylor M. 2010. An overview of second generation biofuel technologies. Bioresource Technol 101(6): 1570-80. doi: 10.1016/j.biortech.2009.11.046

Singh AK, Fernando SD, Hernandez R. 2007. Base-catalyzed fast transesterification of soybean oil using ultrasonication. Energ Fuels 21(2): 1161-4. doi: $10.1021 /$ ef060507g

Singh J, Bargale P. 2000. Development of a small capacity double stage compression screw press for oil expression. J Food Eng 43(2): 75-82. 10.1016/S0260-8774(99)00134-X

Singh S, Singh D. 2010. Biodiesel production through the use of different sources and characterization of oils and their esters as the substitute of diesel: a review. Renew Sust Energ Rev 14(1): 200-16. doi: 10.1016/j.rser.2009.07.017

Sirkar KK, Shanbhag PV, Kovvali AS. 1999. Membrane in a reactor: a functional perspective. Ind Eng Chem Res 38(10): 3715-37. doi: $10.1021 /$ ie990069j

Sotoft LF, Rong B, Christensen KV, Norddahl B. 2010. Process simulation and economical evaluation of enzymatic biodiesel production plant 10.1016/j.biortech.2010.01.130

Stavarache C, Vinatoru M, Maeda Y. 2006. Ultrasonic versus silent methylation of vegetable oils. Ultrason Sonochem 13(5): 401-407. doi: 10.1016/j.ultsonch.2005.08.001

Stavarache C, Vinatoru M, Nishimura R, Maeda Y. 2003. Conversion of vegetable oil to biodiesel using ultrasonic irradiation. Chem Lett 32(8): 716-7. doi: 10.1246/cl.2003.716

Teall R, Sickels RF. 2005. Biodiesel production unit. Patent. US 6979426 B2.

Tremblay A, Cao P, Dubé MA. 2008. Biodiesel production using ultralow catalyst concentrations. Energ Fuels 22(4): 2748-55. doi $10.1021 /$ ef700769v

Tuchlenski A, Beckmann A, Reusch D, Düssel R, Weidlich U, Janowsky R. 2001. Reactive distillation-industrial applications, process design \& scale-up. Chem Eng Sci 56(2): 387-94. doi: 10.1016/S0009. 2509(00)00240-2

van Gerpen J, Shanks B, Pruszko R, Clements D, Konthe G. 2004. Biodiesel production technology. NREL/SR-510-36244.

Vicente G, Martınez M, Aracil J. 2004. Integrated biodiesel production: a comparison of different homogeneous catalysts systems, Bioresource Technol 92(3): 297-305. doi: 10.1016/j.biortech.2003.08.014

Wang Y, Wang X., Liu Y, Ou S, Tan Y, Tang S. 2009. Refining of biodiesel by ceramic membrane separation. Fuel Process Technol 90(3): 422-7. doi: 10.1016/j.fuproc.2008.11.004

Widyarani, Ratnaningsih E, Sanders JPM, Bruins ME. 2014. Biorefinery methods for separation of protein and oil fractions from rubber seed kernel. Ind Crop Prod 62: 323-32. doi: 10.1016/j.indcrop.2014.09.005 
Xie QG, Wirach T, Charongpun M, Chaisri S. 2011. Separation of oily sludge and glycerol from biodiesel processing waste by coagulation. Songklanakarin J Sci Technol 33(6):699-703. 